Andrej Kumar, Ph.D.

ECSA Slovenia, Ljubljana, Slovenia

andrej.kumar@gmail.com

prof. Vinko Kandžija, Ph.D.

ECSA BiH, Mostar, Bosnia and Herzegovina

vinkokandzija2@gmail.com

\title{
IS THERE STILL A FUTURE TO THE REGIONAL TRADE AGREEMENTS?
}

Received: October 15, 2018

Accepted: December 30, 2018

Review

\begin{abstract}
Regional Trade Agreements (RTAs), are Treaties between two or more states to liberalize mutual trade or other economic relations. Among such RTAs the European Union is the largest one and most complex, including 28 member states with developed high levels of trade, monetary and economic cooperation in 2018. Generally RTAs follow the idea that more free trade and more liberal environment for other economic cooperation activities among the integrated states create an environment enabling additional and accelerated economic growth of member states, together with some other positive structural and economic gains. After 1992 the number of newly registered RTAs with GATT and later with WTO started to increase very fast in comparison to the entire period after the WW II. In May 2018 all WTO registered active RTAs reached the number of 287 . The number of active RTA evidently exceeds the number of all world's states. The number of 287 active RTAs suggests that at least some states participate in more than one form of RTA. Such fact further strongly suggests that at least before 2017 there was globally developed an intensive interest among states to join or create one or another form of the RTA. The growth of registered and active RTAs in the last 25 or so years confirms realization of the theoretically predicted positive economic impacts of the RTAs on the member states economic achievements. However Mr. Trump, as the actual President of the USA, started to question expected positive economic gains of the existing RTAs. The policy of unilateral increases of USA'simport tariffs introduced by new USA administration presents open violation of the WTO trading rules. The USA's discriminatory trade policy has been further extended by the decided that USA has to exit from its existing RTAs. USA's decision of dismantling of the existing RTAs creates questions about their real economic efficiency and generally about the future of such international trade agreements. The process and
\end{abstract}


actions after the dismantling and renegotiating of the USA's RTA with Mexico and Canada, known as North American Free Trade Agreement (NAFTA, established Jan.1, 1994) produce some insight into the weaknesses and into the potential changes of the future RTAs.

In the paper we analyse expected economic gains and eventual disadvantages of the RTAs for the member states. The expected end of NAFTA and creation of a new trade agreement between USA, Mexico and Canada are analysed with the purpose to develop insights into the probable future existence and reforms of the RTAs in the global economy.

Keywords: Liberal trade, beggar-thy-neighbour policy, regional trade agreements (RTAs), RTAs and gains, uneven distribution of trade gains or benefits, trade restrictions, North American Free Trade Agreement, new trade agreement USA, Mexico, Canada, non-traditional forms of dumping, RTAs'and reform issues.

JEL: F5, F6

\section{INTRODUCTION}

From the times of Adam Smith and David Ricardo international trade, especially with limited or no state regulation - free or liberal trade-, was supposed and in practical terms it really was, beneficial to all trading nations. Liberal attitude in trade issues was accepted as leading orientation (doctrine) for the economic policy of many nations widely and lastingly. In the past the problem was that liberal trade policies were not always equally appreciated, understood and practice among different trading nations. Especially during and after the Great Economic Depression of the 1930 s (GED) of the $20^{\text {th }}$ century sizable number of nations decided to improve their national economic achievements by policies implementing different new trade restrictive measures together with increasing of the existing classical trade restrictions. The policy of continuously increasing and introducing new trade barriers was simultaneously combined with a policy of excessive national currency exchange rate value depreciations. Combination of discriminatory trade and currencies' exchange rate policies was expected to create necessary economic conditions for a substantial national exports volume growth, together with the decrease in the volumes of national imports. Both economic developments were expected to secure a higher national economic growth that was needed to improve the critically low levels of the national aggregate labour employment.

In general the expected positive impacts of the restrictive and discriminatory trade policy together with the anticipated exchange rate devaluation policy should help the economy to get successfully out of the existing economic crises. The practical short-comes of such economic policies were on one side reduced national economic efficiency and on the other side negative economic and political reactions of the partner countries. The partner countries were production and 
employment negatively affected by the decreasing exports to all the states that had been using discriminatory trade and exchange rate policies. Decrease in national exports started to deepened their national economic crises. The states with falling exports that were caused by the trade protection measures used by partner countries started to experience the accelerated national GDP level decreases together with simultaneous growth of the labour unemployment rates.

The general reaction to such negative and hostile discriminatory trade and exchange rate polices was that nation after nation started to stimulate their national exports and to limit simultaneously national imports. To achieve needed export growth, and expected import decrease the measures of the trade discrimination were increasingly used together with the exchange rate discriminatory practices. Such combination of economic measures was expected to create economic conditions necessary for the reduction of the continuously growing national unemployment rate.

Nowadays the USA trade policy of the unilateral dismantling of the existing Regional Trade Agreements (RTAs) and of unilateral increases of import tariff rates, for selected products and states, is in a great deal similar to the trade and exchange rates discriminatory policies that were used in the period before the WW II.

\section{HISTORIC REASONS AND EVIDENCES OF TRADE AND EXCHANGE RATES DISCRIMINATORY POLICIES}

The historic intensive and broad use of trade and exchange rate discriminatory policies resulted from economic and political problems associated with the impacts of the Great Economic Depression (GED) of the thirties of $20^{\text {th }}$ century. The broad use of trade discriminatory policies caused sizable decrease of the volume of international trade before the World War II (WW II). Discriminatory trade policy was characterised by intensive trade barriers increases and was further associated with the increased level of exchange rate risks. The risks were increased following the practices of the anticipated intensive national currency devaluation policies. Data and analyses of the effects made by trade barriers increases and by the anticipated devaluation policies used during and after GED show generally negative results for employment and economic growth levels.

"Using panel data estimates of export and import equations for 17 countries in the interwar period, this paper estimate the effects of increasing tariff and nontariff trade barriers on worldwide trade over the period 1929 to 1932. The estimates suggest that real world trade contracted approximately $14 \%$ because of declining income, $8 \%$ as a result of discretionary increases in tariff rates, $5 \%$ owing to deflation-induced tariff increases, and a further $6 \%$ because of the imposition of nontariff barriers. Allowing for feedback effects from trade barriers on income and 
prices, discretionary impositions of trade barriers contributed about the same to the trade collapse as the diminishing nominal income." The tariff increases in the period of GED are documented in Table 1.Only the trade restrictions used in period 1929-1932, according to Madsen's calculation, had reduced trade of the analysed 17 states for $19 \%$. Obviously, but not included into the above analyse, there were additional trade reduction effects based on increased trade and payment risks following the policies of anticipated currencies devaluations. Substantially reduced exports together with reduced imports started to affect negatively the level of national incomes, the level of aggregate production and the intensity of the economic growth in all and each of the states that were using discriminatory policies. Negative economic growth effects following the trade discrimination impacts caused further decreases in the levels of the nation aggregate employment. The vicious cycle of economic depression and of growing unemployment was effectively closed by the practice of using trade ad exchange rate discriminatory policies in the efforts of national governments to overcome the highly negative impacts of GED.

Negative national economic results created by the impacts of the trade discrimination that developed into a trade war started to develop new economic and political tensions and conflicts among growing number of states. Before the WW II such ineffective and even dangerous trade and exchange rates discriminatory policy was known as a beggar-thy-neighbour policy.

The term was originally devised to characterize policies of trying to cure domestic depression and unemployment by shifting effective demand away from imports onto domestically produced goods, either through tariffs and quotas on imports, or by competitive devaluations. Such policy can be associated with the concepts of mercantilism and neomercantilism and in theory and practice they open the way for trade wars between countries. Before the WW II trade wars based on the use of the beggar-thy-neighbour policies were unfortunately altogether ineffective attempt to reduce negative impacts of the GED. Negative impacts of the resulting trade wars were, according to a number of professional analyses from the past ${ }^{2}$ and together with some political statement ${ }^{3}$ of the time, among the major causes creating the

\footnotetext{
${ }^{1}$ Madsen, Jakob B.; Trade Barriers and the Collapse of World Trade During the Great Depression, Southern Economic Journal 2001, 67(4), 848-868; http://www.people.vcu.edu/ 1razzolini/GR2001.pdf

${ }^{2}$ French economist Frédéric Bastiat (1801-1850) is often quoted as saying that when goods do not cross frontiers, armies will. Whether he said it or not, it's right. See: https://fee.org/articles/trade-wars-lead-to-shooting-wars-and-depressions/

3 In 1938 the USA Secretary of State Cordell Hull reasoned, "Our nation, and every nation, can enjoy sustained prosperity only in a world which is at peace; a peaceful world is possible only when there exists for it a solid economic foundation, an indispensable part of which is active and mutually beneficial trade among the nations. "For Hull, trade was essential for peace. When he won a Nobel Peace Prize in 1945, the awarding committee 
outbreak of the WW II. As domestic industries weakened by the negative impacts of the beggar-thy-neighbour policies, increasing national political pressures to protect them from foreign competition started to develop. In short trade wars were part of GED and caused very slow economic recovery in Europe, Japan and in both Americas. According to historic facts related to GED and its impacts is evident that trade wars could actually cause even a real shooting war. "In the violent Depression," Winston Churchill ${ }^{4}$ wrote, "Britain and 40 other countries felt increasingly compelled, as the years passed, to apply restrictions or tariffs against Japanese goods produced under labour conditions unrelated to European or American standards." The reasons for the economic tensions between states, explained by W. Churchill, were historically based on "labour conditions unrelated to European or American standards". The reasons related to different "labour standards" that caused trade wars in the past, could unfortunately be equally observed and missus din the global economy of today. In contemporary global economic environment, after his election, Mr. Trump started to "protect" American economic interests by introducing additional import tariffs and by disrupting RTAs that USA had agreed in the past. According to Mr. Trump's reasoning goods produced and imported from China and from other countries including (potentially) the EU countries, are made under labour and other conditions that are unrelated to American standards, so they are harmful for USA economy and USA labour employment levels.

Today's economic situation created by the USA restrictive economic/trade policy introduced by Mr. Trump has a number of similarities with the economic situation in the World before the WW II. Unfortunately economic and trade wars that developed after GED between different states, including Europe and Japan, as

summed up Hull's thinking this way: "High tariffs are barriers obstructing the development of trade and friendship between nations, thereby becoming barriers also to lasting international peace." See:

http://origins.osu.edu/article/trade-wars-collapse-americas-free-trade-consensus

${ }^{4}$ Winston Churchill: "The Gathering Storm," Published May 5th 2005 (first published June 1st 1948),

ISBN 0141441720 (ISBN13: 9780141441726), Series; The Second World War

It is interesting for the nowadays international trade relation policies and for their needed reforms that already before the WW II W. Churchill realized that the international trade competition based on extremely low levels of salaries in fact requires introduction of the specific national trade restrictions. Similar argument was used by President Trump when he renegotiated the "old" NAFTA concepts with Mexico. The issue of production costs in international trade is getting increasing attention following the fact that social, taxation and environmental costs are not globally under the same framework rules or standards. So for example in spite of relative comparative advantage of China or Bangladesh based on their relative labor abundance, the salaries should still cover standardized labor costs like reasonable working conditions protecting cost, reasonable sustainable level of wage etc.. The problem is that the global economy has not yet accepted such standardization of labor costs. 
explained by Mr. Churchill, were among the major causes for the outbreak of the WW II. We should hope that today's similar international economic and political situation will not cause similar negative global effects and developments in the future. However we should be aware that similar problems exist in competitive environment of international trade today as they were present in the past. As in the past, today's global competitive trade problems, if not adequately treated, might cause intensifies trade was among states. Today's trade wars, due to many similarities with the pre WW II period, could unfortunately create eventually as well somehow similar unwonted outcomes.

To understand better what are the reasons for the present international returning to the dangerous historic international economic situation, and to judge how the present unilateral discriminatory use of trade restrictions could develop in the future, we intend to:

- use theory and data to explain trade, trade relations, and trade impacts after the WW II,

- overview the multilateral trade rules (WTO) to understand why in the past they succeeded to enable intensive global trade and economic growth, and further to evaluate if WTO's rules can still be implemented today and in the future,

- Assess the development and impacts of RTAs from the past based on the fact that they developed intensively especially after 1990s and that they contributed significantly to trade growth and to economic globalization.

Describing and assessing the above three trade related issues will help to elaborate conclusions whether the history of mankind in relation between trade War and actual War is possible to be eventually repeated again in our modern times.

\section{ECONOMIC IMPACTS OF INTERNATIONAL TRADE}

Based on traditional trade theory we could accept that trade is beneficial to economic growth of all nations, provided that the theoretically assumed conditions are reasonably well realized in practical circumstances. ${ }^{5}$ To discuss the future of

\footnotetext{
${ }^{5}$ In international trade theory basically the conditions for perfect competition apply (see: https://saylordotorg.github.io/text international-trade-theory-and-policy/s08-02-heckscherohlin-model-assumpti.html). Theoretical trade models are further based on one or more production factors, two or more trading states and two or more traded products. Some newer theories even are not based on perfect competition conditions, other accept product differentiation, technological progress etc. The point is that in practically in and trade theory we could find some assumptions that are actually not fulfilled in reality of global trade developments. Difference between theoretical assumptions and reality doesn't mean that trade theories are entirely wrong and that trade could not be positive and beneficial for trading economies. The differences between reality and theory assumptions only suggest that the theoretically expected sizes of trade impacts are in reality bigger or smaller 
RTAs it is vital to prove that trade is in reality positive to create additional and increased economic growth of the nation. Positive growth effect of trade on trading economy derives from the positive difference between the economy's equilibrium production and consumption points. The positive difference between the two points is based on improved economic results following the production specialization that is made possible in fact only through trade development (Fig.1).

Only trade creates conditions necessary to position the national consumption equilibrium points of the trading countries (Fig.1: points D and O') above their production possibility curve. Trade besides enabling the higher levels of national aggregate consumption enables further production increases based on enlarged national investment consumption which is part of by the trade enlarged aggregate national consumption. If assumption of free trade is only partially fulfilled then consumption points are located lower, closer to national production possibility curves, and the expected positive trade effects are partially more or less reduced.

In such perspective any form of trade liberalization among states, and especially eventual signing and implementing of a RTA could cause, based on eliminating existing trade barriers, an increase in the levels of the national equilibrium aggregate consumption points. Higher levels of aggregate consumption points lead to more investment consumption and consequently to higher economic growth.

compared to theoretical explanations. As a result the actual trade based economic results are (more) unevenly distributed among the trading states. In theoretical explanation of trade impacts used in our paper we assume that theoretical assumptions and trade reality are reasonably closely connected. That means that fundamental theoretically explained trade impacts are generally correct although they could in reality vary by size and location in relation to the different trading participants/states. (For some further explanations see: https://www.nber.org/papers/w8169.pdf) Based on limited size of the paper we leave aside description of further reasons for the actually uneven distribution of trade positive impacts. Such further reasons for the uneven distributing of positive trade benefits are related to the impacts created in international trade by the existence of large international business subjects - multinational/global corporations (MNCs). MNCs additionally distort theoretically expected level and structure of national trade benefits expressed by additional and accelerated national economic growth and employment. The market distortions created by MNCs are and will be eventually controlled and neutralized by implementation of the effective national competition protecting legislation. 
Figure 1. Trade impacts on production and consumption points of the trading economies

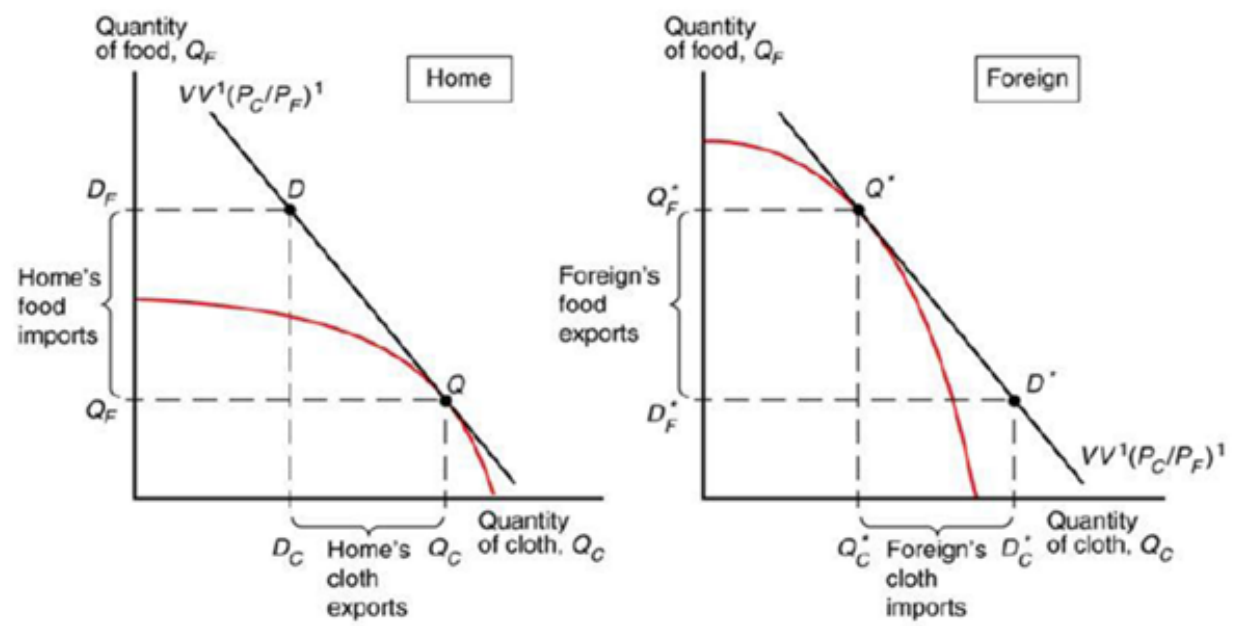

(b) Production, Consumption, and Trade

In our model (Fig. 1) we see another important effect of trade. The increase of the aggregate consumption equilibrium point above the production possibility curve is actually different for each of the trading countries. It is different by its position level relative to national production possibility curve and by its structure of products that form the aggregate of the national consumption. Such differences in impacts created by trade might not be equally appreciated by all trading countries. Unavoidable differences in trade benefits or gains created among trading nations, which are expressed by different level and structure of the national aggregate consumption point, might unfortunately be a trigger of trading tensions among partner countries. In ideal theoretical conditions such consumption points' differences among trading partners are entirely unavoidable and by that they are somehow "natural". The differences in national trade benefits expressed by level and structure of their consumption points are in ideal trade model caused by the differences between the shapes and positions of the national production possibilities curves. Basic differences in the level and structure of consumption points based on trade between nations with the different production possibility curve are unavoidable and so they are some have "natural" and to some extend acceptable for each of the trading nations. In real life differences between the trading partners national consumption points are often enlarged by the fact that in practice only partially a number of specific theoretical conditions that are presumed in the theoretical models are fulfilled and realized.. Among such additional unwonted factors that further create differences in the level and structure of the nations' realized trade benefit or gain could be the following facts; difference in the economic size of the trading economies, difference in the levels of economic and technological development of the trading economies, difference in the national governance efficiency, and some other objective differences. 
In a case of a longer RTA's implementation period, or in a case of practicing rather liberal multilateral trade environment, for a longer period all above mentioned differences affecting distribution of the trade gains start to accelerate and multiply negative effects of the unbalanced trade gains distribution. The satisfaction of partners in the RTA or in the multilateral trading liberalization agreement starts to deteriorate by the passing of time. Decreasing satisfaction with the impacts of the open trade system follows the gradual increase in the unbalanced distribution of the trade gains among RTA's member states or among states members of the multilateral trade agreement.

In the case of the European Union (EU) such unbalanced distribution of RTA's trading gains among partner countries has been recognized from the start. The specific provisions were accepted in the Treaty of Rome (1957), so as to reduce the negative impacts of uneven distribution of the positive trade effects among partner countries ${ }^{6}$.Today the EU cohesion policy performs as at least a partial corrective instrument for the negative impacts developed within the integration on the bases of economic and other differences among partner countries. These differences are expressed in increasingly different levels of realized national aggregate consumption equilibrium points. The EU nations with larger economy, better technological level and better governance enjoy accumulated improvements in the level and structure of their aggregate consumption points based on free trade growth that is RTA's secured. Other members of the EU as well enjoy faster economic progress and increased trade gains as a result of general RTA's and trade growth effects. However the smaller, less efficient or otherwise deprived members of the EU start through time to lag behind the progress of the better suited integration members. The recent increasing national political criticism of the EU in a number of the member states might be a signal that the present cohesion policy of the EU is not in reality any more effective enough in compensating the too large RTA based free trade created differences among the actual levels of the national aggregate consumption points.

The trade gains based on the levels and structures of the national aggregate consumption points are distributed significantly more unevenly when general market competition conditions are distorted from the theoretically ideal situation. The market competition is distorted based on different sizes of partners, based on use of trade and of other regulation measures, based on lack of information, etc. Some of such market and trade cooperation distortions could be corrected by specific provisions included in different existing multilateral agreements like

\footnotetext{
${ }^{6}$ The Treaty of Rome was based on understanding the problems of uneven conditions for realizing similar trade gains among economically different Treaty's partners. So the Treaty ensures (more) balanced trade and fair competition and further envisions reduction of the economic and social differences between the EEC's various regions. The policy that aims to neutralize unbalanced distribution of trade and other integration gains is today known as the EU cohesion policy. See: http://publications.europa.eu/resource/cellar/20ba20c8-6d6e-4901-b16733bed13d6209.0005.02/DOC 4 .
} 
agreements forming the World Trade Organization (WTO). Similarly on more limited scale with regard to a number of participating countries but simultaneously more intensively related to the issues of trade liberalization among the participating states the trade distortions could be effectively reduced by concluding regional trade agreements (RTAs).

\section{TRADE IMPACTS AND MULTILATERAL TRADE RULES AFTER WW II}

After the WWII efforts were made to reach multilateral trading agreements that could generally correct and limit use of numerous instruments for trade distortion that were used in the period of using "beggar-thy-neighbour policies". Efforts for new multilateral trade agreements have been especially focused on eliminating the conditions that could potentially recreate pre WW II economic environment that had made ,a beggar-thy-neighbour policy” generally accepted and practiced policy by most of the trading states. The efforts after WW II to reduce danger of a new world's trade discrimination practices and the efforts to increase the openness of the multilateral trade environment were rather successful. Formally success of the international trade liberalization and non-discrimination efforts are reflected in successful contracting of the General Agreement on Tariffs and Trade (GATT 1947) and in 1995 by establishment of the World Trade Organization (WTO).

Table 1. Average Tariff Levels for the USA and Major European Countries before and after GATT signing

\begin{tabular}{lccccr} 
Country & 1913 & 1925 & 1931 & 1952 & 2007 \\
\hline Belgium & $\mathbf{6}$ & 7 & 17 & n.a. & $\mathbf{5 . 2}$ \\
France & 14 & 9 & 38 & 19 & 5.2 \\
Germany & 12 & 15 & 40 & 16 & 5.2 \\
Italy & 17 & 16 & 48 & 24 & 5.2 \\
UK & n.a. & 4 & 17 & 17 & 5.2 \\
United States & 32 & 26 & 35 & 9 & 3.5 \\
\hline
\end{tabular}

Source:

https://www.brookings.edu/wpcontent/uploads/2016/07/selfenforcingtrade_chapter.pdf

The achievements in trade liberalization are seen through general decreases in the levels of the import tariffs rates (Table 1) during time. Especially after nineties of the twenty century general efforts to make trade growth faster, and more beneficial to the participating states, were increasingly associated with specific trade liberalization agreements known as Regional Trade Agreements (RTAs).

Once negotiated and accepted any type of multilateral trade agreement or of regional trade agreement is in fact a very powerful instrument supporting trade 
growth among partner countries. Multilateral trade agreement is generally more difficult to agree because of often big differences in interests among a large number of negotiating states. Smaller number of states and more economically and culturally similar states negotiating trade liberalization can reach agreement faster and easier. The interest for such trade agreements - for RTAs - was increased after nighties of $20^{\text {th }}$ century when new fast technological progress (Internet, ITC technologies, etc.) started to demand free access to new and larger (foreign) markets so as to increase capital turnover rates. Increase in capital turnover rates made businesses able to accelerate investments into new technologies necessary to keep competitive advantage on national and foreign markets. Although the generic name - RTA - of such trade agreements with a smaller number of partners suggests that partner states are from the same region, the reality is that a modern RTA extends often well across the borders of just a narrow geographic region. If we look for example to the North America Free Trade Agreement we see that it extends over more than one continent. Similarly today's EU, by its membership covers large areas of the continent named Europe. The EU geographically in fact covers such a big part of the continent that (not well informed) people and unfortunately often some politicians instead of saying EU just say Europe. The mistake is on one side misleading and on the other potentially politically dangerous.

After the WW II the GATT was contracted among 23 states $^{7}$ and signed in October 1947. During the years states signatures to GATT succeeded to negotiate control and reduction of tariff rates and of other trade barriers like quantitative restrictions, subsidies etc. (Table 2). GATT successfully promoted progress in trade liberalization and attracted increasing number of contracting states as partners. Partially the number of contracting parties to GATT grew as result of the decolonization process that created a number of new independent states in decades after the WW II. In 1995 GATT was included into a newly created World Trade Organization (WTO). WTO resulted from successful conclusion of the GATT's Uruguay round. WTO rules were in comparison to GATT extended to cover beside trade in goods as well trade in services, trade related issues of intellectual property rights and other topic related to trade including anti-dumping rules and rules on settling the disputes among the member states (Table 2).

Signing of GATT and later successful negotiations in its framework on lowering and controlling different other groups of trade barriers beside tariffs was an unprecedented and successful multilateral negotiation outcome. The underlying principle of reciprocity that served to influence early multilateral trade negotiations turns out to have been an important international force allowing governments to

\footnotetext{
${ }^{7}$ The 23 countries engaging in the Geneva negotiations that led to the signing of the GATT in 1947 were Australia, Belgium, Brazil, Burma (Myanmar), Canada, Ceylon (Sri Lanka), Chile, China, Cuba, Czechoslovakia (Czech Republic and Slovakia), France, India, Lebanon, Luxembourg, Netherlands, New Zealand, Norway, Pakistan, South Africa, Southern Rhodesia (Zimbabwe), Syria, United Kingdom, and United States.
} 
coordinate trade issues and simultaneously lower trade barriers. Furthermore, this reciprocal balance of trade obligation across countries is what has allowed them to keep the trade barriers low toward one another; for the most part of over the 70 years after the first trade and tariff contracts were signed. However the long lasting internationally developed and accepted understanding of the positive impacts developed on the grounds of a reciprocal balance of trade obligations have unfortunately been interrupted after the USA presidential election in November 2016.

Among important achievements of the GATT Uruguay round of negotiations was agreement on "dispute settlement procedure". The procedure is today part of the WTO rules. More detailed analyse of the dispute settlement procedure is of interest especially in the light of the recent USA unilateral increases of selected import tariffs. It is as well interesting for formation of the understanding how WTO members use the dispute settlement process to self-enforce the agreement and maintain reciprocal balance in applying trade barriers. In our paper these issues however interesting they are will not be analysed further due to its size limitations.

\section{Table 2. GATT and WTO Rounds of Multilateral Trade Liberalization negotiations}

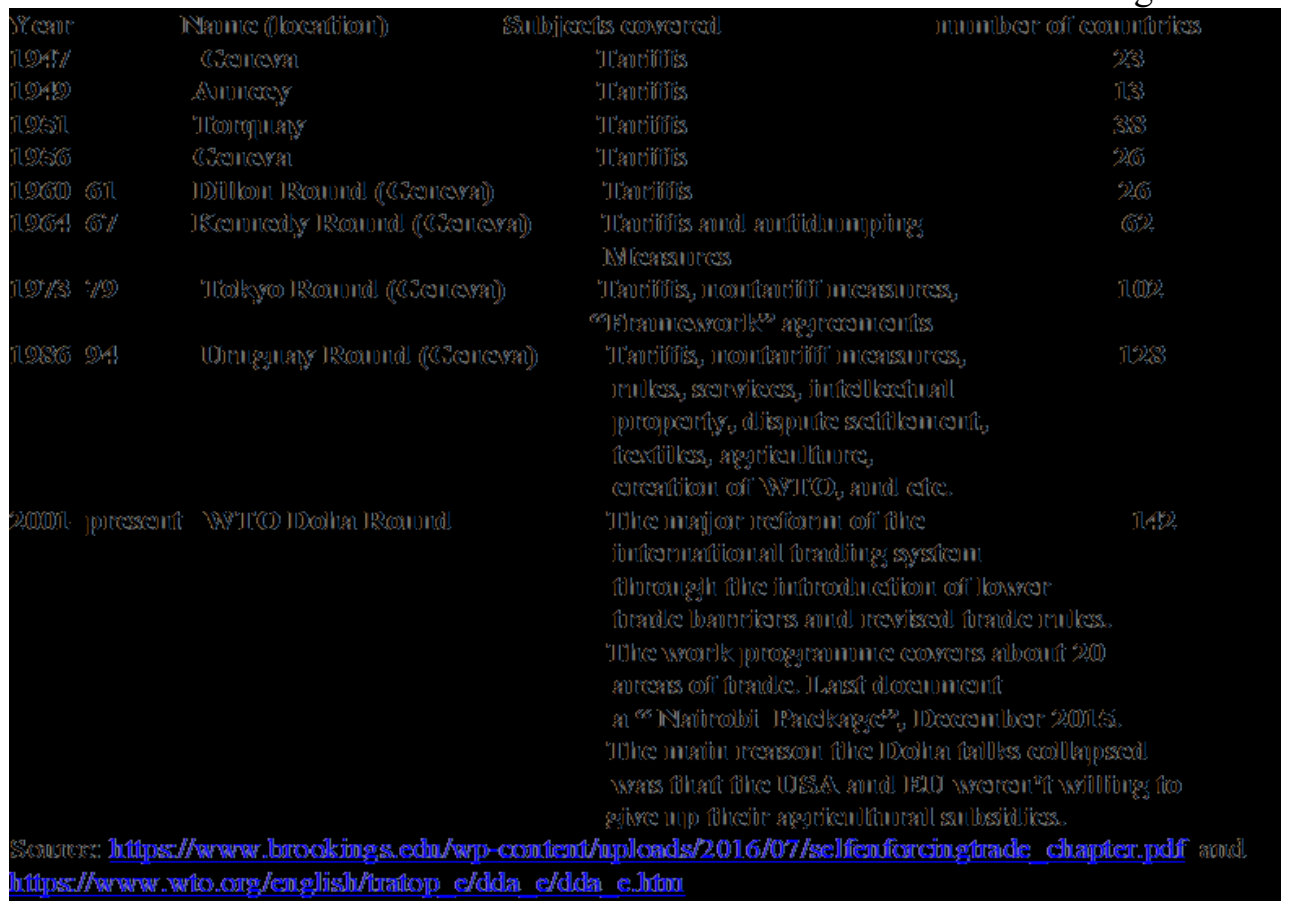

It is however relevant to note in the face of contemporary relatively challenging political and economic circumstances that in the past the WTO dispute settlement procedure was successful in a number of cases including the case of the USA unilateral increase of import tariffs for still products in 2002. 
The steel Safeguard Measure imposed by the United States on 5 March 2002 is an exemplary case of the distortionary impacts of protectionism, resulting from the attempts of the Bush Administration to appease domestic lobbying. The additional tariffs took effect March 20, 2002 and were lifted by Bush on December 4, 2003. Research shows that the tariffs adversely affected US GDP and employment. The temporary tariffs of $8-30 \%$ were originally scheduled to remain in effect until 2005. Canada and Mexico were exempt from the tariffs because of penalties the United States would face under the North American Free Trade Agreement. The Bush administration justified the tariffs as an anti-dumping response, namely that the US steel industry had to be protected against sudden surges of imports of steel. Mr. Trump's administration currently uses similar arguments for its introduction of additional import tariff. The new tariff increases are some have based on assumptions that China and some other countries apply labour price "dumping" practice so as to increase exports to the USA.

The additional USA-Bush steel tariffs ignited international controversy as well. Immediately after they were filed, the European Union (EU) announced that it would impose retaliatory tariffs on the United States, thus risking the start of a major trade war. To decide whether or not the steel tariffs were fair, a case was filed at the WTO Dispute Settlement Body. Japan, Korea, China, Taiwan, Switzerland, Brazil and others joined with similar cases. On November 11, 2003, the WTO came out against the USA additional steel tariffs, saying that they had not been imposed during a period of import surge -- steel imports had actually dropped a bit during 2001 and 2002 -- and that the tariffs therefore were a violation of the USA WTO tariff-rate commitments. The WTO ruling authorized more than \$2 billion in sanctions, the largest penalty ever imposed by the WTO against a member state, if the USA did not quickly remove the illegal additional tariffs. After receiving the verdict, Bush declared that he would preserve the tariffs. After receiving the verdict, Bush's administration declared that the USA would preserve the tariffs. In retaliation, the EU threatened to counter with tariffs of its own on products ranging from Florida oranges to cars produced in Michigan, with each tariff calculated to likewise hurt the President in a key marginal state. The USA reasoned and backed down and withdrew the additional tariffs on December 4, 2003. When he lifted the tariffs, Bush said, "I took action to give the industry a chance to adjust to the surge in foreign imports and to give relief to the workers and communities that depend on steel for their jobs and livelihoods. These safeguard measures have now achieved their purpose, and as a result of changed economic circumstances it is time to lift them". ${ }^{8}$

What lessens could be taken from the past USA additional still tariffs in relation to the present situation when the USA use policies introducing additional tariffs for a number of products imported from different countries and often massively from

\footnotetext{
${ }^{8}$ See: https://en.wikipedia.org/wiki/2002_United_States_steel_tariff
} 
China. Obviously recent USA trade protectionisms much broader in sense of products and states that are export hurt by the present additional USA tariffs. A number of countries - including Mexico, Canada, Turkey, Vietnam, the EU and others - disputed U.S. tariffs on foreign steel, aluminium and other products at meetings of the WTO from summer to outmen of 2018. Rarely has the WTO faced so many disputes about a handful of actions taken by a single state. However President Trump's pursuit of the USA protectionist trade policies practice has stoked nationalism and trade protectionism around the globe. One of the proven effects created by the increasing trade protectionism is and will be negative impacts on the global and national economic growth, The following Figure shows data on the close relation between trade and economic growth in the period 1995 to 2015 . According to theory which defines trade as the engine of economic growth Fig.2, shows that less trade is necessarily related to less economic growth.

Figure 2. Relation between trade and economic growth

\section{Annual percentage growth in world trade and world GDP, 1995-2016}

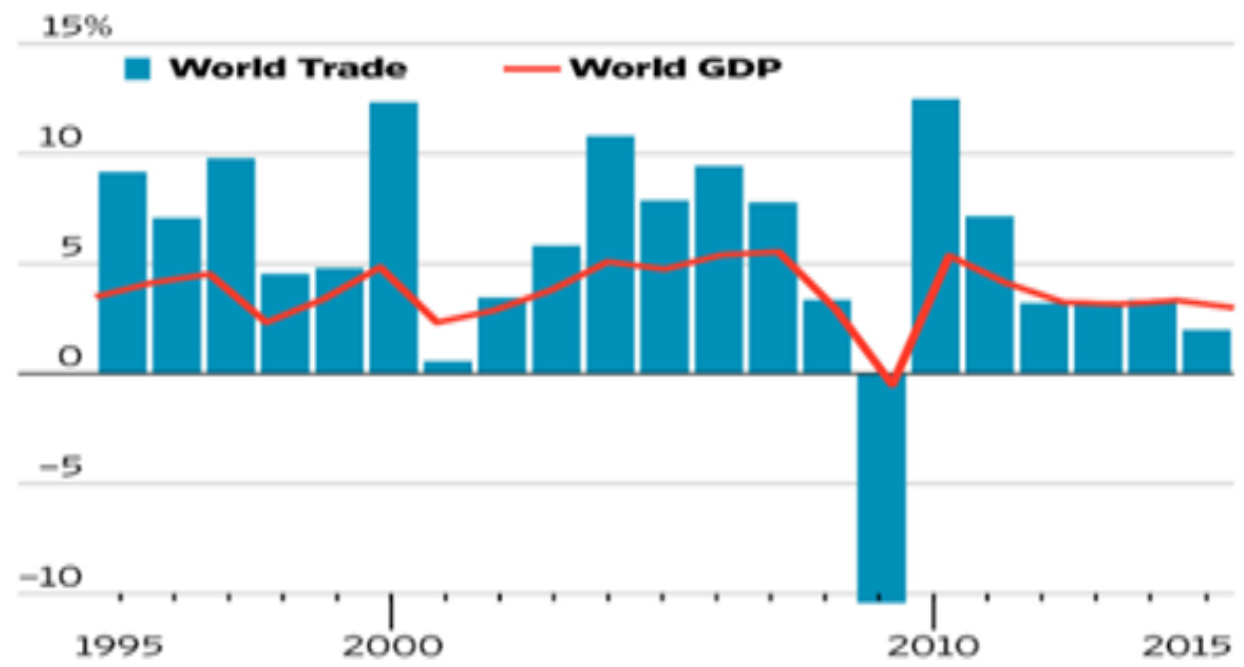

Source: $\quad$ https://itdoesnotaddup.com/2016/04/05/more-trade-faster-economicgrowth/

International trade experts say the protectionist measures taken recently by the USA and some responses to such practices have reviled how fragile and how less effective the WTO trading system has become in last ten or so years. The disputes against the USA filed to the WTO in second half of 2018 will be a critical test of whether the WTO still has the ability to stay efficiently against the open and massive violation of the accepted international trading rules. 


\section{POSSIBLE OUTCOMES OF THE USA CONTEMPORARY TRADE PROTECTIONISM AND THE RTAS}

The Trump's trade protectionist tariffs are a series of additional unilateral tariffs imposed during the presidency of Mr. Donald Trump as part of his economic policy. In January 2018, Trump imposed tariffs on solar panels and washing machines of 30 to $50 \%$. Later in the year he imposed tariffs on steel $(25 \%)$ and aluminium (10\%) from most countries. On June 1, 2018, this was extended on the EU, Canada, and Mexico. The only countries which remain exempted from the steel and aluminium tariffs have been Australia and Argentina. Separately, on July 6, 2018 the Trump administration set a tariff of $25 \%$ on 818 categories of goods imported from China worth $\$ 50$ billion. China is asking the WTO to review the tariffs on roughly half of its exports to the USA. The USA is fighting back with complaints about Chinese counter-tariffs and generally too low export prices that are as was mentioned already often caused by too low level of salaries. Such low prices of labour create potentially a dumping case. The antidumping procedures are accepted within the WTO rules. The anti-dumping procedures based on low level of salaries or on the grounds of so called "social dumping" were used in a very limited number of cases. That leads to conclusion that the present anti-dumping rules legally limit the potential success of the anti-dumping procedures against exports based on using social, environmental, or other specific non-traditional dumping practices ${ }^{9}$.

The outcomes of the WTO dispute settlement procedures related to present USA protectionist practice, are much less possible to predict as they had been in 2003. The reasons are numerous among them is rough and highly selfish behaviour of the USA such as have never been seen or practiced in the entire period after the WW II. Such USA political and economic behaviour make rather slim chances that USA would respect eventual future WTO decision to remove all at the moment too high import tariffs There are further different suspicions present about the actual WTO ability to accept relevant decisions to penalize the USA in case of not removing the too high import tariffs. The suspicions could have a number of arguments but let it be enough to note that WTO, which means its member states, was not able at all to get realised the Doha round negotiations agenda in more than a decade and half long period.

Eventually USA policy of unilateral too high import tariffs could end following bilateral negotiation with major trading partners like China, EU and some others.

\footnotetext{
${ }^{9}$ For antidumping and countervailing USA duties

see: https://help.cbp.gov/app/answers/detail/a_id/219/ /antidumping\%2Fcountervailingduties-\%28list-of-commodities-subject-to-ad\%2Fcvd\%29.

The list of anti-dumping investigations of the USA shows rather low number of Chines product under the current USA investigation. See: https://www.usitc.gov/trade_remedy/731_ad_701_cvd/investigations.htm
} 
Interest to get some consensus with major trading partner about the import tariff levels and about some other trade regulating instruments will grow in the USA when the negative impacts of increased import tariffs will start to show. From historic results of the Bush additional steel import tariffs is evident, in spite of the short period of their use, that the additional import tariffs were in fact negative for the USA economy ${ }^{10}$.

A negative impact of increased import tariff on the economy could be explained by so called net dead weight losses created by imposed higher tariffs. The Fig 2 shows impacts of an import tariff increase. The tariff increase negatively reflects on domestic consumers. Their losses are bigger than are the domestic producers' gains based on increased domestic production. So entire economy performs a net loss based on higher negative impacts on consumption as are the positive impacts of the import tariff on the increased domestic supply. On the bases of the partial equilibrium model the Fig.3 explains the reasons for creation of the net negative result for the economy that uses import tariff,

Figure 3. Negative impact of increased import tariffs (partial equilibrium)

\section{The Effect of an Import Tariff}

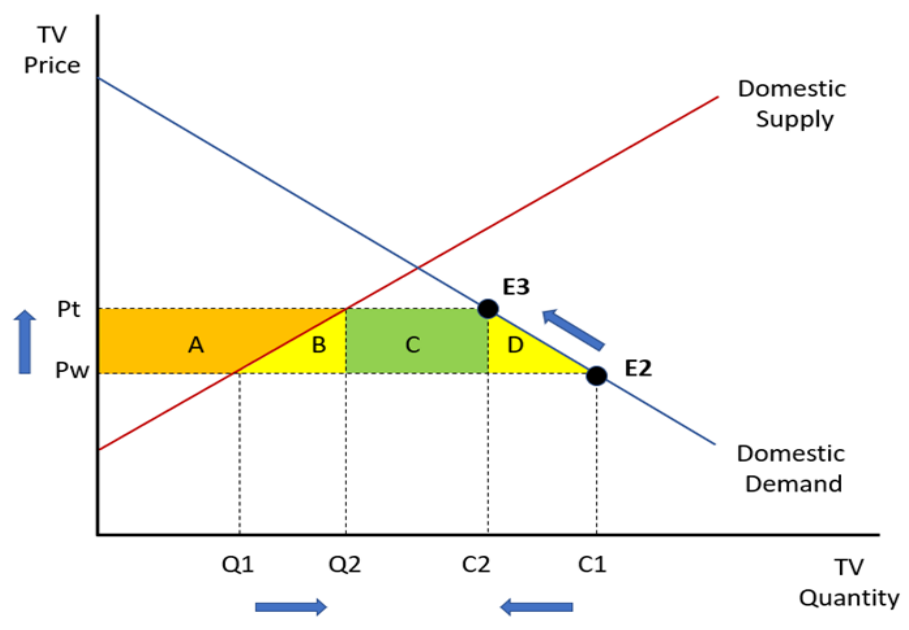

Source: Krugman and Wells "Microeconomics" (2005)

Higher prices and lower consumption quantities reduce consumer surplus (the area above price but under the demand curve) by areas $\mathrm{A}+\mathrm{B}+\mathrm{C}+\mathrm{D}$, while increased producer surplus based on higher import tariff (the area below price but above the supply curve) is presented only by the area A. Import tariffs create new government revenue by the area $\mathrm{C}$ (the imported quantity times the tariff value.) Evidently the areas B and D are national dead-weight losses, resulting from surplus

${ }^{10}$ See: https://en.wikipedia.org/wiki/Trump_tariffs 
lost by consumers and overall. The entire economy following the use of additional import tariffs will (general equilibrium case) drop to a lower level of the national equilibrium consumption point. Use of the higher import tariffs causes further drop of the national equilibrium consumption point level. As observed in the USA such effects were registered already in a short period of the Bush's use of the additional steel import tariffs. In case of broader and more intensive use of increase import tariffs by Mr. Trump one could reasonably expect similar but larger negative impacts for the USA economy. The period needed to show the negative economic impacts of the additional tariffs use is not clearly evident in the USA case. That is so because of relatively small share (around 12\% in 2016) of exports of goods and services in the total USA GDP ${ }^{11}$.

Besides using unilaterall increases of the import tariffs as part of the USA trade policy Mr. Tramp's administration has accepted a number of decisions that entirely negate the US's obligations and membership in a number of the agreed and valid RTAs. The most interesting development in the area of the contemporary USA protectionist trade policy is the one-sided attempt to terminate free trade agreement with Mexico and Canada - NAFTA. End of August 2018 the US President has announced that he intends to dump the nearly 25-year-old NAFTA agreement, making it the latest deal to be targeted as part of his "America First" trade strategy. Later President Trump notified the Congress of his plans to sign an agreement with Mexico in 90 days to replace NAFTA. And despite earlier suggestions that he may cut Canada out of the agreement altogether Mr. Trump was later suggesting that Canada could be brought into a new RTA agreement of the three countries too. Under the USA pressure the negotiation on a new trade agreement - new RTA with Mexico and Canada was concluded fast. Trump, Canadian Prime Minister Justin Trudeau and outgoing Mexican president Enrique Peña Nieto signed a new trade agreement already on Nov.30, 2018. The new RTA agreement is named the United States-Mexico-Canada Agreement (USMCA) ${ }^{12}$. Formally the USA and both other NAFTA members had the right to withdraw from NAFTA. Under Article 2205 of the NAFTA, a country can withdraw from the agreement by providing a six-month notice to fellow signatories. This means Trump could had, in theory, send a letter of notice to Canada and Mexico indicating his intent to withdraw from Agreement. But, according to professional comments, the president would have first needed congressional approval to actually terminate US involvement in NAFTA. Not in the negotiations with the USA trading partners for a new agreement and not in the internal USA required procedure to terminate NAFTA the normally expected and formally valid procedures were respected. While the USA, Mexico, and Canada have concluded a new, reshaped RTA agreement, the old NAFTA agreement however currently remains in effect. The USMCA can come

\footnotetext{
${ }^{11}$ See: https://www.statista.com/statistics/258779/us-exports-as-a-percentage-of-gdp/

12 See: https://www.theguardian.com/us-news/2018/dec/02/trump-terminate-nafta-formalnotice-congress, and https://ustr.gov/trade-agreements/free-trade-agreements/united-statesmexico-canada-agreement
} 
into effect following the completion of TPA procedures ${ }^{13}$, including a Congressional vote on an implementing bill.

Our goal in this paper is to understand better the future use and importance of the RTAs in the global trade relations following the fact that in last couple of years international trading system is dominated and in the process of reshaping by the "new" USA's trade protectionist policy. Before getting closer to our analytical goal and before making further explanation of the major changes contained in the process of changing NAFTA into USMCA, we would shortly show the importance of the existing RTAs in global trade relations after the WW II, when free trade agreements mostly started to be negotiated to regulate trade cooperation among member states.

After the WW II among the very early agreed RTAs was an agreement that is today known as the European Union (EU). The EU started with six countries as its members and was partial type of economic integration. The first EU free trade and economic integration Treaty established the European Coal and Steel Community (1951). Later in 1957 the same member states concluded agreement on establishing The European Economic Community (EEC) and the European Community for atomic Energy (Euro atom) ${ }^{14}$.

\footnotetext{
${ }^{13}$ For more than 30 years, the USA Congress has enacted Trade Promotion Authority (TPA) laws to guide both Democratic and Republican Administrations in pursuing trade agreements that support U.S. jobs, eliminating barriers in foreign markets and establishing rules to stop unfair trade. See:

https://ustr.gov/trade-agreements/other-initiatives/Trade-Promotion-Authority

${ }^{14}$ For better historic and conceptual over wide of the free trade cooperation development and of the broader economic integration performed among increasing number of the European states see: https://europa.eu/european-union/about-eu/history_en. It is good to note that trade and economic cooperation of the today's EU member state have from the beginning covered economic cooperation aspects broader as just sole free trade cooperation issues.
} 
Figure 4. Number of concluded and active (black line) registered by WTO (19482014)

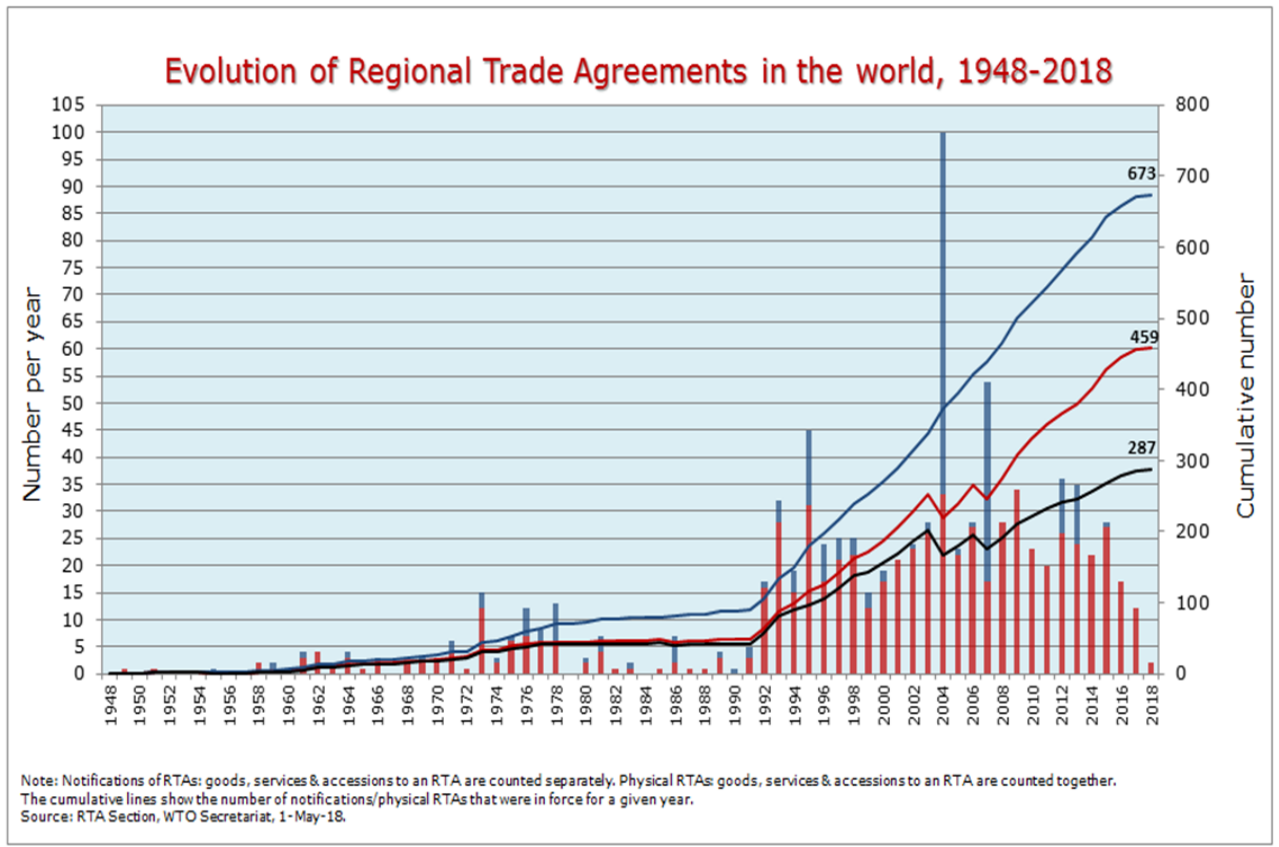

After the WW II the interest to sign treaties on establishing new RTA among two or more states was always an interesting international trade cooperation option. However the real explosion in the number of agreed RTAs happened after nighties of $20^{\text {th }}$ century (Fig. 4). RTAs have always been used as a vehicle to create faster trade and economic cooperation possibilities among specific groups of the GATT contracting parties.

The relevant question is what happened that the number of RTAs registered by GATT and after 1995 by WTO had started to increase intensively during the last decade of the 20th century and later. There are number of different reason for explosive growth in the number of registered and active RTAs signed among different groups of the GATT contracting parties and later among member states of the WTO. Among major reason for RTAs number growth are economic impacts imposed globally by the beginning of an accelerated general global technological process. Technological progress started to develop with unprecedented speed in the last few decades of the $20^{\text {th }}$ century. The fast technological progress was mostly related to exponential increase in the increasing number of inventions in sectors of computing, informatics, communication, transport and in other sectors like biotechnology, Nano technology etc.

The technological progress in computer chips is well known-but surprisingly, it isn't a special case. A range of other technologies demonstrate similar exponential growth, whether bits of data stored or DNA base pairs recorded. The outcome is 
the same: capabilities have increased by thousands, millions, and billions for less cost in just decades ${ }^{15}$.To make it short, new technologies offer competitive advantages to nations and companies if implemented fast and if used to make chipper and better products and to create further new technological inventions. To do so new investments in relative short investment cycles are critical and necessary. The trade as we noted already makes new and increased investment possible. Need to implement and use advantages of new technologies pushed states towards the need to improve market openness and foreign markets accessibility so as to create favourable conditions for more and faster growing trade. By opening economies and by creating more trade successful states wanted to enable opportunities for the new growing business to increase and accelerate investments especially into new technologies. New and growing investments are made possible by increased trade growth that accelerates national income growth. Opening of markets and improving access to foreign markets is a demanding and time consuming effort standing before the new national trade and economic policy implementation. Multilateral trade negotiations take a lot of time and are often difficult to finalize as a tool to open markets and to improve markets access. Slowness and complexity of multilateral trade negotiation could be convincingly illustrated by unsuccessful Doha WTO agenda negotiations that have been going on unsuccessfully for a little less than two decades already. The needs for increased investments and the needs for accessing larger open markets to enable required faster and larger capital investments turnover have convinced a growing number of states to use a faster option for realization of open access to new and larger markets. Such faster option for getting more open and more accessible new foreign markets has realized through negotiations with a limited number of partners. After negotiations partner states accept a specific free trade arrangement. Such agreement is based on one or another form of the Regional Trade Agreement (RTA) concepts that is acceptable and allowed by the GATT or today by the WTO rules.

The need for more trade and so the need for concluding new RTAs was intensive and even intensifying in the last few decades. The need for new RTAs was growing parallel with the acceleration of the technological progress in the entire global economy. The benefits and gains of increased trade are already explained, as are explained already the specific trade system conditions that could distort the balanced and fair distribution of trade gains and benefits. Trade system distorted conditions in practice enlarge the problem of unequal distribution of trade gains among partner states and within each of the states. Through passing of the time the problem with unbalanced distribution of trade gains is accumulated into distorted distribution of trade gains among the partner states. Accumulation of the unbalanced trade gains distribution in real life could escalate into different tensions

\footnotetext{
${ }^{15}$ Technology Feels Like It's Accelerating - Because It Actually Is; https://singularityhub.com/2016/03/22/technology-feels-like-its-accelerating-because-itactually-is/\#sm.0001txnz78mqdegry5b1r29ems42a
} 
and even into new protectionist behaviour among partner countries. The solution for such negative development is to agree on renegotiation of the RTA or of some other trade agreement provisions. Further in such negotiations partner countries could further agree on implementing RTA specific corrective measures that will neutralize too large distortions in trade gains distribution ${ }^{16}$. The problems of too large distortions in trade gains distribution among partner countries probably are reflected in the present protectionist trade policy of Mr. Trump and in his tuff approach in renegotiating the NAFTA. Studying the American trade policy under the Presidency of Mr. Trump, in the environment of increasingly unbalanced distribution of the trade gains, makes two observe possible. First observation reflects the fact that USA trade policy today is based on rough one sided and selfish power based negotiation methods. Such methods of negotiation are combined with unconventional blunt ignorance of international obligations that USA has accepted in relation to different international agreements and institutions. An example of such blunt USA obligations ignoring practice is present protectionist trade policy that violates the WTO trading rules. The second observation developed from the present USA trade policy practice is that in substance the recant USA one sided negative reactions towards the existing trade cooperation issues somehow help to unearth some relevant and existing trade gains distribution problems. Such problems have been accumulating during the last few decades in the USA economy and general in the majority of states within the global economy.

Before focusing more on trade gains distribution problems in relation to NAFTA renegotiation let make some reflections on the issue of the good or bad future of the RTAs in general. RTAs obviously have the future as part of international trading system provided that eventual distorted distribution of trade gains and accumulation of such distortions in time could be fairly renegotiated and if necessary as well compensated by agreed trade measures among the RTA member states. As the actualities prove of the correctness about the RTAs' explained future existence the NAFTA renegotiation into new RTA of USMCA could be convincingly used following the following facts. The first option of the new USA trade policy was to exit unilaterally from NAFTA. Later the idea was to leave Canada out of a new agreement. The final result is however just the new name of agreement and redesigned and in relevant areas corrected content of the renegotiated free trade agreement - RTA. All three states ream as partners in the new RTA.

\footnotetext{
${ }^{16}$ The case of such corrective policy is already mentioned as the EU Cohesion policy.
} 


\section{THE NAFTA NEGATIONS AND THE FUTURE OF THE INTERNATIONAL TRADING SYSTEM}

To better understand reasons that often create dissatisfaction with the impacts created by the present international trading system a swift analyse of the NAFTA renegotiation case might be of certain help. In renegotiating the NAFTA some specific issues that are relevant for causing distorted distribution of trade gains among trading states were opened, discussed and agreed upon. Renegotiation of NAFTA was obviously based on one-sided interest of the USA to follow the realization of the political idea contained in the words: "America first". However a number of discussed and renegotiated issues in creating USMCA from NAFTA were and still are highly relevant for understanding the causes of the existing problems creating increasing distortions in the process of trade gains distribution among states trading in the framework of the contemporary international and RTA based trading systems. In the future multilateral and RTAs trade system renegotiation efforts will have to focus on correcting the "week" parts of the present international trading system. The identification of the weak parts that are contained in the present international trading system might be much easier if the expected future reforms of international trading system will be organized around the topics that were accepted as problems that create distortions in the trade gains distribution between the NAFTA member states. The idea that USA's one-sided trade interests and the related definition of trade distortion used in the NAFTA renegotiations process might be accepted as relevant in the future reform of the international trading system could look strange and wrong at least at the first glance. The surprise about using the renegotiation issues of NAFTA to discuss international trading system reform will be smaller if we recall the fact that international trade, whether based on multilateral agreements or on RTAs, creates the distribution of trade gains inequalities that are larger in practice as in the theory. The issues renegotiated within NAFTA in a number of cases respond to "unnecessary" trade related distortion that cause increased deformation in the trade gains distribution balances.

The problems that were discussed during the renegotiation of NAFTA were in the scope of existing reasons producing the unnecessarily large inequalities in the global trade gains distribution. The official USA description of their expected negotiation achievements shows there, and by some generalization, as well the actual global trade gains and benefits distribution problems."When finalized and implemented, the agreement will create more balanced, reciprocal trade that supports high-paying jobs for Americans and grows the North American economy. Agreement highlights include:

- Creating a more level playing field for American workers, including improved rules of origin for automobiles, trucks, other products, and disciplines on currency manipulation. 
- Benefiting American farmers, ranchers, and agribusinesses by modernizing and strengthening food and agriculture trade in North America.

- Supporting a 21 st Century economy through new protections for U.S. intellectual property, and ensuring opportunities for trade in U.S. services.

- New chapters covering Digital Trade, Anticorruption, and Good Regulatory Practices, as well as a chapter devoted to ensuring that Small and Medium Sized Enterprises benefit from the Agreement." 17

From the above explanation of the objectives that were followed by the USA in their renegotiation of the NAFTA a set of relevant conclusions for the future trading and RTA system reform could be constructed.

The USA felt that their trade with partners was not properly balanced, so they stress "agreement will create more balanced, reciprocal trade". As noted already in the case of the EU some political options feel similar. Trade gains and other benefits of the EU membership in perception of some member states and in the perception of some nationalist orientated political options are not properly balanced among all member states. Rather similar observations could be seen in official or political statement all around the world. To reform world's trading system so that more balanced trade gains distribution could be secured the elements that in practice cause more than just theoretically expected differences in sizes and structures of the gains based on trade development mast be renegotiated, assessed and reshaped. Which are such elements in the international trading system that in practice too much distort functioning of the international trading system? To answer the question the NAFTA renegotiation issues could help.

The first issue renegotiated within NAFTA is related to a USA statement that new trade agreement should create a more level playing field for American workers. The "levelled playing field" goal in global trade environment refers to a problem of extremely low salaries payment levels that are actual often in (less)developed states. The use of too low level of salaries in production and in service industry obviously distorts the trade competition and by that provides unnecessary distortions in the distribution of trade gains among states and people. The problem of (too) low salaries used to create more export could be evaluated as a form of "social duping". Unfortunately according to the WTO anti-dumping rules proofing the fact that certain salaries are to low and so the exports product prices are too low is legally very difficult. Consequently the introduction of anti-dumping measures in case of exports that are based on the too low level of salaries is practically not possible. The reform of the anti-dumping rules in salaries case could reduce one part of reasons for the distortions in trade gains distribution. The reform of anti-

\footnotetext{
${ }^{17}$ See: https://ustr.gov/trade-agreements/free-trade-agreements/united-states-mexicocanada-agreement
} 
dumping rules become even more actual and necessary by the realization of the fact that some sort of dumping practice to push exports is in many cases based further on not respecting - not paying - the standard levels of labour safety and protection costs, of environment protection costs and even of taxation costs. In the last case the unfair competition is created when exports are being pushed by using specific state's taxation policy measures. To reach agreed internationals standards for the mentioned costs is no doubt a demanding task. However it is to decide what is more problematic to overcome: the costs and efforts of performing successful standardization negotiations or to accept the danger of further trade wars escalation in the future. Although negotiations on mentioned costs standardization to secure more fare competition in international trade are complex and difficult the fact is that international community already has on its disposal for negotiations number of existing relevant institutions together with their basic rules that can together be implemented to make the process of negotiations easier and faster. Among such institutions are; WTO, International Labour Organization, some other United Nation specialized agencies, and a number of other international and regional economic organizations and agreements. Obviously the problems of reaching necessary agreements on trade and broader economic system reform are not related to the eventual lack of international institutions. Actual problem to start and finalize discussion on the trade system reform is in fact related to lack of understanding that new agreed trade rules are necessary for the future benefit of all states.

The NAFTA renegotiation achievement can help to understand better way negotiations about the above mentioned costs and about some other not here specified issues of trade gains distortions are in fact necessary. The new eventually negotiated standardization agreements will bring additional trade benefits to all participating states. The NAFTA performance in past years was a huge economic and foreign policy success. Trade between U.S. and Mexico has greatly increased since 1994. In last years about $40 \%$ of the imports value from Mexico consisted of content originally made in the U.S. Although the NAFTA performance was successful its renegotiation supports the idea that international trading system reform is needed at list in some specific segments that distort the proper functioning of the international competitive environment.

Accepting the idea of a needed trading system reform should not cover up the fact that actual employment and growth problems of some states are not caused only by the trading system's imperfections. Based on results of different analyses technology progress, not trade and RTAs, was behind the losses of the manufacturing jobs in advanced economies, including USA. Between 2000 and 2010 in USA, employment in manufacturing fell by 5.6 million. But productivity growth accounted for $85 \%$ of job losses, only $15 \%$ resulted from trade ${ }^{18}$. Since trade is (often) not the only or major key cause for job losses, trade protectionism is not

${ }^{18}$ See: https://itdoesnotaddup.com/2016/06/28/why-free-trade-is-so-important/ 
the adequate solution. Although technology and other developments affect employment and growth the proper treatment of the problems of too low salaries and of the other to low costs have still to be treated and standardized on the international scale. Without cots standardization in international trading system the danger of trade wars continuation will remain high and continuously present. Similarly agreed corrections in some other fields of unfair trade competition are necessary to keep international trade as the engine of growth and global economic progress in the future. Among such other necessary corrections are regulations improving the rules of origin, especially for certain groups of products. Further there is a need for: improved rules on preventing the currency manipulation for trade effects, improved protection of intellectual property rights, ensuring stable and more transparent opportunities in services trade and new rules regulating the area of digital trade.

\section{CONCLUSION}

The World Trading System that was created after the WWII has increasing problems to provide stability and trade development that secures global and national economic growth and prosperity. Competition distortions accumulated in the post WWII trading environment are among the reasons for the increasing dissatisfaction with the realized international trade impacts among and within different nations. Job losses, unequal distribution of incomes and of trade gains are just some of the problems accompanying present global trading relations. The problems related to present global trading system created a need for reforms. The problems of competition distortions, problems of large discrepancies in trade gains distribution and some other problems stimulate development of increasingly negative national and individual economic, social and political reactions to the impacts that are based on increasing trade openness created by multilateral and regional trade agreements. Among contemporarily most dangerous reactions to the problems created by the poor functioning of today's international trade system are probably the USA's unilateral use of new and increased trade barriers, and their cancellations of existing RTAs obligations. USA trade practice of the last two years seriously re-establishes the danger of actual repeating of the pre WWII policy practice known as ,a beggar-thy-neighbour policy“. Such trade policy potentially leads to trade wars and to other conflicts and tensions in the global environment.

USA aggressive trade protectionist practice might be unfortunately soon followed by other big and economically strong nations. Such situation calls for fast and relevant reform of present international trade system. The dialog on reform can be started within existing global organizations and agreements.

Some topics relevant to the international trade system reform are known and they are as already noted surprisingly adequately addressed in the new RTA between USA, Mexico and Canada. The USA renegotiation of NAFTA offers some inside into the probable new future provisions of RTAs around the world. RTAs are and 
will be needed as an effective tool for faster and deeper trade liberalization among a limited number of members. RTAs in the future will have to pay more attention to secure the more balanced trade gains distribution among partner counties, so as to make RTA a more stable and lasting trade cooperation instrument.

\section{REFERENCES}

1. Antidumping and countervailing USA duties see: https://help.cbp.gov/app/answers/detail/a id/219/ /antidumping\%2Fcounter vailing-duties- $\% 28$ list-of-commodities-subject-to-ad $\% 2 \mathrm{Fcvd} \% 29$

2. Bastiat, Frédéric (1801-1850) see: https://fee.org/articles/trade-wars-leadto-shooting-wars-and-depressions/

3. Chines product under the current USA investigation: see : https://www.usitc.gov/trade_remedy/731_ad_701_cvd/investigations.htm

4. Churchill, Winston: "The Gathering Storm," Published May 5th 2005 (first published June 1st 1948), ISBN 0141441720 (ISBN13: 9780141441726), Series; The Second World War,

5. Hull, Cordell: see: http://origins.osu.edu/article/trade-wars-collapseamericas-free-trade-consensus

6. International trade theory: see: https://saylordotorg.github.io/text international-trade-theory-and-policy/s0802-heckscher-ohlin-model- assumpti.html and https://www.nber.org/papers/w8169.pdf

7. Madsen, Jakob B.; Trade Barriers and the Collapse of World Trade During the Great Depression, Southern Economic Journal 2001, 67(4), 848-868; http://www.people.vcu.edu/ Irazzolini/GR2001.pdf

8. Technology Feels Like It's Accelerating - Because It Actually Is; https://singularityhub.com/2016/03/22/technology-feels-like-its-acceleratingbecause-it-actually-is/\#sm.0001txnz78mqdegry5b1r29ems42a

9. The Treaty of Rome: http://publications.europa.eu/resource/cellar/20ba20c86d6e-4901-b167-33bed13d6209.0005.02/DOC 4

10.Trade Promotion Authority (TPA): https:/ustr.gov/trade-agreements/otherinitiatives/Trade-Promotion-Authority

11.Trade share in USA BDP: https://www.statista.com/statistics/258779/usexports-as-a-percentage-of-gdp/

12.United States-Mexico-Canada Agreement: https://www.theguardian.com/usnews/2018/dec/02/trump-terminate-nafta-formal-notice-congress,$\quad$ and https://ustr.gov/trade-agreements/free-trade-agreements/united-statesmexico-canada-agreement

13.USA - NAFTA renegotiation goals: https:/ustr.gov/trade-agreements/freetrade-agreements/united-states-mexico-canada-agreement

14. Why Free Trade Is So Important: https://itdoesnotaddup.com/2016/06/28/why-free-trade-is-so-important/ 